C.H. Chen

M.F. Fuller

\section{The effects of non-protein energy supplements on muscle protein synthesis during feeding and fasting}

Postprandiale und postabsorptive Muskelproteinsynthese

Supplementation of a balanced diet with non-protein energy has long been known to promote $\mathrm{N}$ retention (1). The predominant oxidation of carbohydrate during the postprandial phase and oxidation of fatty acids during the post-absorptive phase suggests that, although these substrates may be equally effective in improving $\mathrm{N}$ retention, their underlying mechanisms may be different. Given the diurnal rhythm of muscle protein synthesis found in meal-fed rats (2), it is possible that carbohydrate and fat may exert their protein sparing effects during different periods of a feeding and fasting cycle. The experiment is set out to test this hypothesis.

Female rats, growing $(\sim 150 \mathrm{~g})$ or adult $(-300 \mathrm{~g})$, were trained for $10 \mathrm{~d}$ to eat all their fixed daily ration in $8 \mathrm{~h}$. They were then given for $14 \mathrm{~d}$ either a basal diet or the same diet supplemented with carbohydrate or fat, doubling the intake of that nutrient in each case. At the end of the feeding period on day 14 , half the rats on each treatment were given a flooding dose of $\mathrm{L}-\left[2,6{ }^{3} \mathrm{H}\right]$ phenylalanine for measuring the fractional rate of muscle protein synthesis. The other rats were fasted for $16 \mathrm{~h}$ before being given the injection. Exactly $10 \mathrm{~min}$ after the injection the rats were killed and samples of gastrocnemius muscle were rapidly removed for the measurement of protein synthesis, as described by Garlick et al. (3). Results are shown in Table 1.
Table 1 Fractional protein synthesis rates in the gastrocnemius muscle of young and adult rats given a basal diet or the same diet supplemented with carbohydrate or fat

\begin{tabular}{|c|c|c|c|c|c|c|}
\hline & \multicolumn{3}{|c|}{ Supplement } & \multicolumn{3}{|c|}{ ANOVA } \\
\hline & $\begin{array}{c}\text { None } \\
\text { (control) }\end{array}$ & Fat & Carbohydrate & $\begin{array}{l}\text { Fed vs } \\
\text { Fasted }\end{array}$ & $\begin{array}{l}\text { Control vs } \\
\text { supplement }\end{array}$ & $\begin{array}{l}\text { Feeding } x \\
\text { supplement }\end{array}$ \\
\hline $\begin{array}{l}\text { Young } \\
\text { Fed } \\
\text { Fasted }\end{array}$ & $\begin{array}{l}7.9 \pm 0.51^{a} \\
6.0 \pm 0.32^{c}\end{array}$ & $\begin{array}{l}9.1 \pm 0.41^{b} \\
9.3 \pm 0.64^{b}\end{array}$ & $\begin{array}{l}9.8 \pm 0.33^{b} \\
9.3 \pm 0.22^{b}\end{array}$ & P.05 & P.001 & NS \\
\hline $\begin{array}{l}\text { Adull } \\
\text { Fed } \\
\text { Fasted }\end{array}$ & $\begin{array}{l}4.2 \pm 0.10^{0} \\
3.7 \pm 0.19^{9}\end{array}$ & $\begin{array}{l}4.6 \pm 0.15^{\text {de }} \\
5.0 \pm 0.23^{\text {et }}\end{array}$ & $\begin{array}{l}5.3 \pm 0.20^{\prime} \\
5.0 \pm 0.12^{\text {ef }}\end{array}$ & NS & P.05 & P.05 \\
\hline
\end{tabular}

Values are means $\pm S E M$

Values within age groups without a common superscript (young: a-c; adult: d-g) are significantly different $\quad(\mathrm{P} 0.05)$

The results show that, in young rats, there were no differences between the protein sparing effects of carbohydrate and fat. Both supplements stimulated postprandial muscle protein synthesis and prevented the postabsorptive decrease in protein synthesis. In adult rats, carbohydrate supplement stimulated postprandial muscle protein synthesis and this effect was sustained during the postabsorptive period. The fat supplement, in contrast, did not stimulate postprandial muscle protein synthesis but prevented the postabsorptive decrease in protein synthesis seen in controls.

\section{C.H. Chen - M.F. Fuller}

The Rowett Research Institute

Greenburn Road

Bucksburn

Aberdeen AB21 9SB

UK

\section{References}

1. Munro $H N$ (1951) Physiol Rev 71:449-488

2. Garlick PJ, Millward DJ, James WPT (1973) Biochem J 136:935-945

3. Garlick PJ, McNurlan MA, Preedy VR (1980) Biochem J 192:719-723 